\title{
BUDIDAYA PADI (Oryza sativa) DALAM WADAH DENGAN BERBAGAI JENIS PUPUK PADA SISTEM TANAM BERBEDA
}

\author{
Armaeni Dwi Humaerah*
}

\begin{abstract}
ABSTRAK
Penelitian ini bertujuan untuk mengetahui pengaruh system tanam (hidroponik dan non hidroponik), ukuran wadah (pot) dan pupuk majemuk terhadap pertumbuhan dan produksi tanaman padi. Penelitian dilaksanakan dalam bentuk percobaan, menggunakan rancangan petak-petak terbagi (split-split plot design). Petak utama adalah sistem budidaya (S), terdiri atas dua perlakuan yaitu sistem non-hidroponik (s1) dan hidroponik (s2). Sebagai anak petak adalah diameter wadah tanam (pot) (W), terdiri atas dua taraf, yakni pot berdiameter $30 \mathrm{~cm}$ (w1) dan pot berdiameter $40 \mathrm{~cm}$ (w2), sedangkan anak-anak petaknya adalah jenis pupuk majemuk (P) dengan tiga perlakuan yakni pupuk organik cair Super V3 Hartani (p1), pupuk hyponex (p2) dan pupuk AB mix (p3). Setiap perlakuan dikombinasikan dan diulang sebanyak 3 kali sehingga terdapat 36 unit perlakuan. Masing-masing unit perlakuan terdiri terdiri atas 2 tanaman sehingga keseluruhan terdapat 72 tanaman. Hasil pengamatan dan pengukuran dianalisis dengan menggunakan analisis ragam (ANOVA) dan bila ada perlakuan yang berpengaruh nyata dilanjutkan dengan uji BNT pada taraf alpha 0,05. Adapun hasil penelitian ini adalah Sistem tanam konvensional dapat memberikan pertumbuhan dan produksi tanaman padi yang lebih tinggi dari pada sistem hidroponik. Namun demikian, sistem hidroponik dapat memberikan hasil yang cukup layak untuk dikembangkan. Diameter pot mempengaruhi jumlah malai yang dihasilkan tanaman padi. Diameter $40 \mathrm{~cm}$ lebih menghasilkan malai yang lebih banyak daripada pot berdiameter 30 cm. Pupuk Super V3 Hartani, Hyponex dan AB mix tidak memberikan pengaruh berbeda terhadap pertumbuhan dan produksi tanaman padi. Tidak ada interaksi antara sistem tanam, diameter pot dan jenis pupuk dalam memperngaruhi pertumbuhan dan produksi tanaman padi.
\end{abstract}

Kata kunci: beras, ukuran pot, Hyponex, AB campuran, POC, Hidroponik

\begin{abstract}
This study aims to determine the effect of cropping systems (hydroponics and non hydroponics), size of container (pot) and compound fertilizers on the growth and yield of rice. The research was conducted in the form of experiment, using a design of divided plots (split-split plot design). The main plot is a cultivation system (S) consisting of two treatments that are non-hydroponic system (s1) and hydroponics (s2). As a subplot, there is diameter
\end{abstract}


of the planting container (pot) (W) consisting of two levels, namely the pot diameter $30 \mathrm{~cm}$ (w1) and the pot diameter $40 \mathrm{~cm}(w 2)$, while the needs of subplots are the type of compound fertilizer $(P)$ with three treatments namely the treatment of liquid organic of fertilizer Super V3 Hartani (p1), fertilizer Hyponex (p2) and fertilizer mix AB (p3). Each treatment is combined and repeated three times so that there are 36 treatment units. Each unit consists of two plants so that overall there are 72 plants. Observations and measurements are analyzed by using analysis of variance (ANOVA) and BNT test is occupied to notice whether there is a significant effect of treatment at the level of alpha 0.05. The results of this study show that the conventional cropping systems can deliver higher growth and yield of rice than the hydroponic system. Nevertheless, hydroponic systems can deliver enough results to be developed. Diameter of the pot affects the number of panicles produced by rice plants. Diameter of $40 \mathrm{~cm}$ produces more panicles than diameter of $30 \mathrm{~cm}$. Fertilizer Super V3 Hartani, Hyponex and $A B$ mix do not give a different effect on the growth and yield of rice. There is no interaction between the cropping system, the diameter of the pot and the type of fertilizer to affect the growth and yield of rice.

Keywords: Rice, Pot size, Hyponex, AB mix, POC, Hydroponic

\section{PENDAHULUAN}

Beras merupakan makanan pokok lebih dari $95 \%$ penduduk Indonesia. Selain itu, bercocok tanam padi juga telah menyediakan lapangan pekerjaan bagi sekitar 20 juta rumah petani di pedesaan, sehingga dari sisi ketahanan pangan nasional fungsinya menjadi amat penting dan strategis (Balitpa, 2009). Oleh sebab itu ketersediaan beras harus selalu terjamin karena dapat menyebabkan kerawanan bila terjadi kekurangan stok.

Pesatnya laju pertumbuhan penduduk sebesar 1,94\% per tahun (lebih dari 237 juta jiwa pada tahun 2010 menurut data BPS) menyebabkan meningkatnya kebutuhan terhadap beras sementara pertumbuhan produksinya tidak sebanding dengan permintaan, bahkan cenderung melandai (levelling 0ff). Laju pertumbuhan penduduk yang tinggi juga berpengaruh terhadap kebutuhan lahan untuk keperluan non pertanian seperti perumahan, pusat perbelanjaan, industri atau fasilitas umum lainnya seperti jalan layang, jalan tol dan sebagainya. Akibatnya, terjadi alih fungsi lahan pertanian ke non-pertanian yang semakin sulit terkendali. Diperkirakan laju alih fungsi lahan sawah adalah 100.000 hektar per tahun. Alih fungsi ini sangat nyata terlihat di perkotaan, terutama kotakota besar yang penduduknya sangat padat seperti wilayah Jakarta dan sekitarnya sehingga praktis lahan-lahan pertanian khususnya lahan sawah menjadi semakin sempit. Akibatnya, kemampuan lahanlahan pertanian di perkotaan dalam memenuhi kebutuhan pangan semakin berkurang sehinga tergantung pada pasokan bahan pangan dari luar kota. Hal ini dapat menyebabkan kerawanan bila terjadi sesuatu yang di luar dugaan, misalnya 
bencana alam di wilayah pemasok atau terputusnya jalur distribusi karena banjir dan lain-lain.

Salah satu cara yang dapat ditempuh untuk menyiasati sempitnya lahan pertanian terutama di perkotaan adalah bercocok tanam di dalam pot atau wadah. Cara ini sudah lama digunakan untuk tanaman hias dan beberapa jenis tanaman sayuran seperti cabe ataupun tomat. Namun menanam padi dalam pot belum banyak dilakukan. Apalagi dengan sistem hidroponik.

Nutrisi pada sistem hidroponik dapat diperoleh melalui pupuk majemuk atau pupuk yang dibuat khusus untuk hidroponik. Salah satu diantaranya adalah pupuk ABmix. Namun demikian pupuk ini tidak umum dijual di pasaran. Untuk itu perlu diteliti apakah jenis pupuk majemuk lainnya seperti hyponex dan POC yang lebih mudah dijumpai di pasaran dapat menjadi sumber hara bagi sistem hidroponik.

Penelitian mengenai penggunaan pupuk hyponex pada sistem hidroponik tanaman tomat telah dlakukan oleh Kusuma dkk. (2010). Hasilnya menunjukkan bahwa pupuk Hyponex memberikan jumlah daun yang lebih banyak dan waktu berbeunga serta berbuah yang lebih cepat dibanding pupuk Gandasil D dan Vitabloom.

Meskipun tanaman padi bukan termasuk komoditi dengan harga premium seperti cabe atau tomat hidroponik, namun posisinya sebagai komoditi strategis sangat rawan apabila terjadi penurunan pasokan, sehingga perlu dijaga keberadaanya setiap saat. Dengan sistem hidroponik, produksi dapat terjamin sepanjang tahun tanpa tergantung pasokan dari luar daerah apalagi dari luar negeri. Penelitian ini merupakan langkah awal untuk mengetahui kelayakan padi hidroponik sebagai alternatif pengembangan produksi padi di masa depan.

\section{Tujuan dan Manfaat Penelitian}

Penelitian ini bertujuan untuk mengetahui pengaruh sistem tanam (hidroponik dan non hidroponik), ukuran wadah (pot) dan pupuk majemuk terhadap pertumbuhan dan produksi tanaman padi. Hasilnya diharapkan dapat memberi sumbangsih bagi program peningkatan produksi tanaman padi dan pemanfaatan lahan-lahan sempit di perkotaan.

\section{Hipotesis}

1. Sistem hidroponik dapat memberikan produksi tanaman padi yang cukup memadai sehingga layak untuk dikembangkan.

2. Diameter pot sebagai wadah tanam memberikan pengaruh berbeda terhadap pertumbuhan dan produksi tanaman padi.

3. Berbagai jenis pupuk majemuk memberikan pengaruh yang berbeda terhadap pertumbuhan dan produksi tanaman padi.

4. Terdapat interaksi antara sitem tanam, diameter pot dan berbagai jenis pupuk dalam mempengaruhi pertumbuhan dan produksi tanaman padi.

\section{METODE PENELITIAN}


Tempat dan Waktu Penelitian

Penelitian ini dilaksanakan di green house (rumah tanaman) Prodi Agribisnis, Fakultas Sains dan Teknologi UIN Jakarta yang beralamat di Jalan Asrama Putra (samping gedung Kopertais wilayah IV), Pisangan, Kecamatan Ciputat Timur, Kota Tangsel, mulai Juni sampai November 2013.

\section{Bahan dan Alat}

Bahan-bahan yang digunakan adalah benih padi varietas Sintanur, tanah, arang sekam, pupuk AB mix, pupuk organik cair (Super V3 Hartani), pupuk Hyponex hijau (NPK 20:20:20), pupuk kandang, pestisida, kantong plastik dan label.

Alat-alat yang digunakan adalah pot hitam dengan diameter $30 \mathrm{~cm}$ dan 40 $\mathrm{cm}$, ember, baskom, sekop, sendok tanah, cangkul, kored, timbangan, embrat, handsprayer, gelas ukur, meteran, gunting dan alat tulis menulis.

\section{Rancangan Penelitian}

Penelitian dilaksanakan dalam bentuk percobaan, dengan menggunakan rancangan petak-petak terbagi (split-split plot design). Petak utama adalah sistem budidaya (S), terdiri atas dua perlakuan yaitu sistem non-hidroponik (s1) dan hidroponik (s2). Sebagai anak petak adalah diameter wadah tanam (pot) (W), terdiri atas dua taraf, yakni pot berdiameter $30 \mathrm{~cm}$ (w1) dan pot berdiameter $40 \mathrm{~cm}$ (w2), sedangkan anak-anak petaknya adalah jenis pupuk majemuk $(\mathrm{P})$ dengan tiga perlakuan yakni pupuk organik cair Super V3 Hartani (p1), pupuk hyponex (p2) dan pupuk $A B$ mix (p3). Setiap perlakuan dikombinasikan dan diulang sebanyak 3 kali sehingga terdapat 36 unit perlakuan. Masing-masing unit perlakuan terdiri terdiri atas 2 tanaman sehingga keseluruhan terdapat 72 tanaman. Hasil pengamatan dan pengukuran dianalisis dengan menggunakan analisis ragam ANOVA) dan bila ada perlakuan yang berpengaruh nyata dilanjutkan dengan uji BNT pada taraf $\alpha=0,05$.

\section{Pelaksanaan Penelitian}

Langkah awal adalah menyemaikan benih padi. Sebagai wadah semai digunakan nampan plastik dengan media tanam tanah dicampur dengan pupuk kandang dengan perbandingan 1:1. Sambil menunggu benih tumbuh, media tanam dipersiapkan. Untuk sistem hidroponik, media yang digunakan adalah arang sekam, sedangkan untuk non hidroponik digunakan media tanah dicampur dengan pupuk kandang dengan perbandingan 1:1. Sebelum diisi media, pot dilapisi dengan plastik untuk menutupi lubang pot sehingga air tidak keluar dari pot. Setelah itu, media disiram sampai mencapai kondisi macak-macak.

Setelah berkecambah dan berumur 10 hari, semai dipindahkan ke wadah tanam. Setelah itu tanaman dipupuk seminggu setelah tanam sesuai dengan perlakuan masing-masing. Untuk pupuk hyponex digunakan dosis 1 gram/liter air, POC Super V3 Hartani 6 ml/l air sedangkan pupuk AB mix $5 \mathrm{ml} /$ liter air. Pemberian pupuk dilakukan setiap 5 hari dengan cara disiramkan sebanyak $500 \mathrm{ml}$ larutan untuk setiap tanaman. Selain itu dilakukan 
pemeliharaan lainnya seperti penyulaman, penyiangan, penyiraman dan pemberantasan hama dan penyakit.

\section{Pengamatan}

1. Komponen-komponen diamati adalah:

2. Tinggi tanaman, diukur pada umur 4 dan 8 minggu setelah tanam.

3. Jumlah anakan, dihitung semua jumlah anakan yang terbentuk pada umur 4,8 dan 10 minggu setelah tanam.

4. Jumlah anakan produktif, dihitung semua anakan yang menghasilkan malai pada tiap rumpun dan dilakukan pada saat panen.

5. Jumlah bulir per malai (bulir), dihitung jumlah bulir pada tiap malai dengan mengambil 5 malai pada setiap rumpun sebagai sampel.

\section{HASIL DAN PEMBAHASAN}

\section{Hasil}

Tabel 1 menyajikan ringkasan dari hasil analisis ragam pengaruh berbagai perlakuan terhadap setiap parameter yang diamati. Hasil untuk tiap parameter diuraikan sebagai berikut :

\section{Tinggi Tanaman}

Hasil analisis statistika menunjukkan bahwa perlakuan sistem tanam dan interaksi antara sistem tanam dan diameter pot berpengaruh nyata terhadap tinggi tanaman pada umur 4 minggu setelah tanam, sedangkan pada umur 8 minggu setelah tanam, hanya perlakuan sistem tanam yang berbeda nyata.

Tabel 1. Hasil analisis ragam pengaruh berbagai perlakuan terhadap paramater- parameter yang diamati

\begin{tabular}{|c|c|c|c|c|c|c|c|}
\hline Parameter & $\begin{array}{c}\text { Sistem } \\
\operatorname{tanam}(\mathrm{S})\end{array}$ & $\begin{array}{l}\text { Diameter } \\
\text { pot }(W)\end{array}$ & $\begin{array}{c}\text { Jenis } \\
\text { pupuk }(\mathrm{P})\end{array}$ & $\mathrm{S} \times \mathrm{W}$ & $\mathrm{S} \times \mathrm{P}$ & $\mathrm{W} \times \mathrm{P}$ & $\mathrm{SxWxP}$ \\
\hline $\begin{array}{l}\text { Tinggi tanaman } \\
\text { umur ( } 4 \text { MST) }\end{array}$ & $*$ & tn & $\operatorname{tn}$ & $*$ & $\operatorname{tn}$ & tn & tn \\
\hline $\begin{array}{l}\text { Tinggi tanaman } \\
\quad(8 \mathrm{MST})\end{array}$ & $*$ & tn & tn & $\operatorname{tn}$ & tn & tn & tn \\
\hline Anakan (4 MST) & $*$ & tn & tn & $\operatorname{tn}$ & $\operatorname{tn}$ & $\operatorname{tn}$ & tn \\
\hline Anakan (8 MST) & $*$ & tn & tn & $\operatorname{tn}$ & $\operatorname{tn}$ & tn & $\operatorname{tn}$ \\
\hline $\begin{array}{c}\text { Anakan (10 } \\
\text { MST) }\end{array}$ & $*$ & tn & tn & $\operatorname{tn}$ & $\operatorname{tn}$ & th & tn \\
\hline Jumlah malai & $*$ & $*$ & tn & $\operatorname{tn}$ & $\operatorname{tn}$ & $\operatorname{tn}$ & $\operatorname{tn}$ \\
\hline $\begin{array}{l}\text { Jumlah bulir per } \\
\text { malai }\end{array}$ & $*$ & tn & tn & $\operatorname{tn}$ & $\operatorname{tn}$ & tn & tn \\
\hline
\end{tabular}


Ket.: $\mathrm{MST}=$ minggu setelah tanam

tn = tidak nyata

* = berbeda nyata pada taraf $\alpha=0,05$

Hasil uji BNT menunjukkan bahwa sistem tanam biasa (non-hidroponik) menghasilkan tanaman yang lebih tinggi pada umur 4 minggu setelah tanam dibanding sistem hidroponik. Interaksi antara sistem hidroponik dan ukuran wadah juga berpengaruh, dimana sistem nonhidroponik dengan diameter wadah $30 \mathrm{~cm}$ menghasilkan tanaman tertinggi, sedangkan yang terendah diperoleh pada perlakuan hidroponik dengan diameter wadah $30 \mathrm{~cm}$.

Analisis ragam terhadap tinggi tanaman pada umur 8 minggu ( 2 bulan) setelah tanam menunjukkan hasil yang sedikit berbeda. Pada umur ini, hanya perlakuan tunggal sistem tanam yang berpengaruh nyata, sedangkan perlakuan tunggal lainnya serta interaksi tidak ada yang berbeda.

\section{Jumlah Anakan}

Hasil analisis ragam terhadap jumlah anakan pada umur 4 minggu (1 bulan) setelah tanam menunjukkan hal yang hampir sama dengan hasil analisis terhadap tinggi tanaman, dimana hanya faktor sistem tanam yang memberikan pengaruh nyata, demikian pula dengan hasil analisis jumlah anakan pada umur 8 minggu ( 2 bulan) setelah tanam dan 10 minggu.

Tabel 2. Tinggi tanaman padi $(\mathrm{cm})$ pada umur 4 minggu setelah tanam

\begin{tabular}{lccccc}
\hline \multirow{2}{*}{ Sistem tanam (S) } & Ukuran wadah & \multicolumn{3}{c}{ Jenis pupuk (P) } & \multirow{2}{*}{ Rataan } \\
\cline { 3 - 5 } & No) & POC & Hyponex & AB mix & \\
\hline Non-hidroponik $_{\text {Rataan: 55,94 }}^{\mathrm{a}}$ & Diameter $30 \mathrm{~cm}$ & 57,33 & 49,00 & 66,33 & $57,56^{\mathrm{a}}$ \\
Hidroponik & Diameter $40 \mathrm{~cm}$ & 64,00 & 53,00 & 46,00 & $54,33^{\mathrm{b}}$ \\
Rataan : 38,56 & Diameter $30 \mathrm{~cm}$ & 30,33 & 33,00 & 31,00 & $31,44^{\mathrm{d}}$ \\
\hline
\end{tabular}

Ket: angka-angka yang diikuti oleh huruf yang berbeda, berarti berbeda nyata pada taraf uji BNT 0,05 $(\mathrm{NP}$ S $=0,94 ; \mathrm{NP}$ SW $=3,04$ )

Tabel 3. Tinggi tanaman padi $(\mathrm{cm})$ pada umur 8 minggu setelah tanam

\begin{tabular}{llccc}
\hline \multirow{2}{*}{ Sistem tanam (S) } & \multirow{2}{*}{ Ukuran wadah (W) } & \multicolumn{3}{c}{ Ponis pupuk (P) } \\
& & \multicolumn{2}{c}{ Hyponex } & AB mix \\
\hline Non-hidroponik & Diameter $30 \mathrm{~cm}$ & 79,00 & 64,67 & 77,00 \\
Rataan: 78,39 & Diameter $40 \mathrm{~cm}$ & 92,67 & 79,67 & 77,33 \\
Hidroponik & Diameter $30 \mathrm{~cm}$ & 39,33 & 53,33 & 45,33 \\
Rataan : $53,72^{\mathrm{b}}$ & Diameter $40 \mathrm{~cm}$ & 36,67 & 75,67 & 72,00 \\
\hline
\end{tabular}

Ket: angka-angka yang diikuti oleh huruf yang berbeda, berarti berbeda nyata pada taraf uji BNT 0,05 $(\mathrm{NP} \mathrm{S}=4,28)$ 
Tabel 4. Jumlah anakan tanaman padi (anakan) pada umur 4 minggu setelah tanam

\begin{tabular}{llccc}
\hline \multirow{2}{*}{ Sistem tanam $(\mathrm{S})$} & \multirow{2}{*}{ Ukuran wadah $(\mathrm{W})$} & \multicolumn{3}{c}{ Jenis pupuk $(\mathrm{P})$} \\
& & POC & Hyponex & AB mix \\
\hline Non-hidroponik & Diameter $30 \mathrm{~cm}$ & 5,67 & 4,67 & 9,00 \\
Rataan: $6,17^{\mathrm{a}}$ & Diameter $40 \mathrm{~cm}$ & 7,33 & 7,33 & 3,00 \\
Hidroponik & Diameter $30 \mathrm{~cm}$ & 1,00 & 1,33 & 0,67 \\
Rataan : $1,17^{\mathrm{b}}$ & Diameter $40 \mathrm{~cm}$ & 0.33 & 2,33 & 1,33 \\
\hline
\end{tabular}

Ket: angka-angka yang diikuti oleh huruf yang berbeda, berarti berbeda nyata pada taraf uji BNT 0,05 $(\mathrm{NP} \mathrm{S}=0,38)$

Tabel 5. Jumlah anakan tanaman padi (anakan) pada umur 8 minggu setelah tanam

\begin{tabular}{llccc}
\hline \multirow{2}{*}{ Sistem tanam $(\mathrm{S})$} & \multirow{2}{*}{ Ukuran wadah $(\mathrm{W})$} & POC & Hyponex & AB mix \\
\hline Non-hidroponik & Diameter $30 \mathrm{~cm}$ & 42,67 & 21,67 & 34,33 \\
Rataan:35,78 a & Diameter $40 \mathrm{~cm}$ & 56,33 & 32,67 & 27,00 \\
Hidroponik & Diameter $30 \mathrm{~cm}$ & 4,00 & 25,67 & 4,00 \\
Rataan : $9,56^{\mathrm{b}}$ & Diameter $40 \mathrm{~cm}$ & 4.33 & 21,00 & 14,00 \\
\hline
\end{tabular}

Ket: angka-angka yang diikuti oleh huruf yang berbeda, berarti berbeda nyata pada taraf uji BNT 0,05 $(\mathrm{NP} \mathrm{S}=5,31)$

Tabel 6. Jumlah anakan tanaman padi (anakan) pada umur 10 minggu setelah tanam

\begin{tabular}{llccc}
\hline \multirow{2}{*}{ Sistem tanam $(\mathrm{S})$} & \multirow{2}{*}{ Ukuran wadah $(\mathrm{W})$} & Jenis pupuk (P) & \\
& & POC & Hyponex & AB mix \\
\hline Non-hidroponik & Diameter $30 \mathrm{~cm}$ & 46,67 & 24,33 & 35,67 \\
Rataan: 41,06 & Diameter $40 \mathrm{~cm}$ & 63,67 & 40,00 & 36,00 \\
Hidroponik & Diameter $30 \mathrm{~cm}$ & 4,00 & 8,00 & 5,67 \\
Rataan : $10,72^{\mathrm{b}}$ & Diameter $40 \mathrm{~cm}$ & 4.33 & 24,67 & 17,67 \\
\hline
\end{tabular}

Ket: angka-angka yang diikuti oleh huruf yang berbeda, berarti berbeda nyata pada taraf uji BNT 0,05 $(\mathrm{NP} \mathrm{BNT}=3,78)$

Dari Tabel 4, 5 dan 6 terlihat pula bahwa laju pertambahan jumlah anakan pada sistem konvensional lebih tinggi daripada sistem hdroponik. Namun demikian, persentase anakan produktif pada sistem hidroponik lebih tinggi daripada sistem konvensional seperti terlihat pada Tabel 7.

\section{Jumlah anakan produktif}

Hasil pengamatan jumlah anakan produktif disajikan pada Tabel 7. Analisis ragam menunjukkan bahwa hanya perlakuan sistem tanam yang berpengaruh nyata, sedangkan perlakuan tunggal lainnya maupun interaksi antar perlakuan tidak berpengaruh nyata. 


\section{Jumlah bulir per malai}

Hasil analisis ragam terhadap jumlah bulir per malai juga tidak berbeda dengan parameter lainnya, dimana perlakuan sistem tanam berpengaruh nyata, sedangkan perlakuan lain dan interaksi antar perlakuan tidak berbeda. Hasil uji BNT menunjukkan tanaman yang ditanam pada media tanah memberikan jumlah bulir yang lebih banyak dibanding pada sistem hidroponik. Namun persentase perbedaan jumlah bulir antara kedua perlakuan tidak setinggi persentase perbedaan anakan produktif.

\section{Pembahasan}

Dari hasil analisis ragam terlihat bahwa secara umum tanaman padi yang ditanam pada media tanah (non-hidroponik) memberikan hasil yang lebih baik untuk semua parameter yang diamati, sedangkan perlakuan lainnya tidak menunjukkan hasil yang berbeda nyata, kecuali perlakuan ukuran wadah (pot) untuk parameter jumlah anakan produktif (malai). Diduga hal ini disebabkan oleh kandungan unsur hara pada media tanah yang secara alami lebih tinggi dan lebih lengkap dibanding pada media hidroponik yang terdiri dari sekam bakar.

Tabel 7. Jumlah anakan produktif tanaman padi (anakan)

\begin{tabular}{|c|c|c|c|c|}
\hline \multirow{2}{*}{ Sistem tanam (S) } & \multirow{2}{*}{ Ukuran wadah (W) } & \multicolumn{3}{|c|}{ Jenis pupuk (P) } \\
\hline & & POC & Hyponex & $\mathrm{AB}$ mix \\
\hline Non-hidroponik & Diameter $30 \mathrm{~cm}$ & 32,00 & 15,33 & 25,00 \\
\hline Rataan:35,78 a & Diameter $40 \mathrm{~cm}$ & 60,00 & 32,67 & 33,33 \\
\hline Hidroponik & Diameter $30 \mathrm{~cm}$ & 4,00 & 25,67 & 4,00 \\
\hline Rataan : $9,56^{\mathrm{b}}$ & Diameter $40 \mathrm{~cm}$ & 4.33 & 21,00 & 14,00 \\
\hline
\end{tabular}

Ket: angka-angka yang diikuti oleh huruf yang berbeda, berarti berbeda nyata pada taraf uji BNT 0,05 $(\mathrm{NP} \mathrm{BNT}=5,61)$

Tabel 8. Jumlah bulir per malai tanaman padi (butir)

\begin{tabular}{lllll}
\hline \multirow{2}{*}{ Sistem tanam (S) } & \multirow{2}{*}{ Ukuran wadah $(\mathrm{W})$} & \multicolumn{3}{c}{ Jenis pupuk $(\mathrm{P})$} \\
& & POC & Hyponex & AB mix \\
\hline Non-hidroponik & Diameter $30 \mathrm{~cm}$ & 126,67 & 146,33 & 134,00 \\
Rataan: $143,39^{\mathrm{a}}$ & Diameter $40 \mathrm{~cm}$ & 174,00 & 155,33 & 124,00 \\
Hidroponik & Diameter $30 \mathrm{~cm}$ & 106,67 & 118,67 & 99,33 \\
Rataan : $117,44^{\mathrm{b}}$ & Diameter $40 \mathrm{~cm}$ & 96.33 & 154,00 & 129,67 \\
\hline
\end{tabular}

Ket: angka-angka yang diikuti oleh huruf yang berbeda, berarti berbeda nyata pada taraf uji BNT 0,05 $(\mathrm{NP} \mathrm{BNT}=5,38)$

Tanah pada sistem non-hidroponik dicampur dengan pupuk kandang terlebih dahulu sehingga meningkatkan kualitas tanah yang digunakan. Pupuk kandang selain berfungsi memperbaiki struktur tanah, juga memperbaiki sifat kimia dan biologi tanah. 
Menurut Balittanah (2013), unsur hara yang dikandung pupuk kandang (sapi) adalah nitrogen sebanyak $0,4 \%$, fosfor 0,2 $\%$, Kalium 0,1 \% dan air 85\%. Selain itu, pupuk kandang juga mengandung unsur hara mikro meskipun dalam jumlah yang sangat kecil. Sedangkan arang sekam (sekam bakar) mengandung senyawasenyawa kompleks yang tidak dapat secara langsung menyediakan unsur hara bagi tanaman seperti terlihat pada Tabel 9.

Tabel 9. Komposisi Kimiawi Arang Sekam

\begin{tabular}{lc}
\hline \multicolumn{1}{c}{ Komponen } & Kandungan $(\%)$ \\
\hline Kadar air & 9,02 \\
Protein kasar & 3,03 \\
Lemak & 1,18 \\
Serat kasar & 35,68 \\
Abu & 17,71 \\
Karbohidrat & 33,71 \\
Karbon & 1,33 \\
Hidrogen & 1,54 \\
Oksigen & 33,64 \\
Silika $\left(\mathrm{SiO}_{2}\right)$ & 16,98 \\
\hline
\end{tabular}

Sumber : Pustaka Litbang Deptan (2013)

Meskipun sistem hidroponik pada penelitian ini hasilnya lebih rendah daripada sistem konvensional, namun memberikan hasil yang cukup menjanjikan. Hasil dari penelitian ini menunjukkan bahwa padi dapat dibudidayakan secara hidroponik, meskipun masih diperlukan banyak penelitian lanjutan agar hasilnya dapat menyamai atau bahkan melebihi sistem tanam konvensional. Faktor-faktor yang mungkin perlu diteliti antara lain dosis pupuk, frekuensi pemberian pupuk, cara pemberian pupuk, media hidroponik dan sebagainya. Penggunaan sistem hidroponik substrat juga perlu dipertimbangkan mengingat penggunaan arang sekam pada penelitian ini hasilnya rendah, terlihat dari jumlah anakan produktif yang hanya mencapai $50 \%$ dari potensinya.

Budidaya padi di dalam pot dengan media tanah dicampur pupuk kandang ternyata hasilnya sangat menggembirakan. Ini terlihat dari rata-rata jumlah malai (anakan produktif) yang dihasilkan (35,78 malai), yang jauh melampai potensi ratarata jumlah malai varietas Syntanur yang berada pada kisaran 16-20 malai.

Untuk perlakuan ukuran wadah (pot), pengaruhnya yang nyata hanya terlihat pada parameter jumlah anakan produktif (malai). Namun demikian, nilai rata-rata untuk wadah berdiameter $40 \mathrm{~cm}$ secara umum lebih tinggi daripada yang berdiameter 30 $\mathrm{cm}$. Selain itu, pengaruhnya yang nyata terlihat pada parameter jumlah malai. Hal ini penting karena yang dipengaruhi adalah produksi tanaman. Karena adanya masalah teknis, bobot gabah untuk tiap malai tidak dapat dihitung pada penelitian ini, namun produksi tanaman dapat tercermin dari jumlah malai dan jumlah bulir yang terbentuk. Ukuran wadah (pot) dengan diameter $40 \mathrm{~cm}$ memberikan jumlah malai yang lebih tinggi daripada diameter $30 \mathrm{~cm}$. Hal ini logis, sebab wadah yang lebih besar dapat menampung media yang lebih banyak, sehingga unsur hara dan air yang tersedia bagi tanaman juga lebih besar. Hal ini sudah dapat diduga sebelumnya, namun yang ingin diketahui adalah sampai sejauh mana ukuran wadah ini memberikan hasil yang berbeda nyata secara statistik dan secara ekonomi tidak memberatkan, karena 
makin besar ukuran wadah harganya juga akan semakin mahal. Untuk itu diperlukan penelitian lanjutan mengenai analisis biaya dan pendapatan yang optimal untuk tiap ukuran wadah, yang tidak tercakup dalam penelitian ini.

Jenis pupuk tidak memberikan pengaruh nyata terhadap seluruh parameter yang diamati. Ini diduga karena kandungan unsur hara pada ketiga jenis pupuk tidak jauh berbeda. Meskipun komposisinya berbeda-beda, namun perbedaan tersebut tidak memperikan pengaruh nyata, karena umumnya pupuk dibuat untuk memenuhi kebutuhan tanaman. Kecuali untuk kondisi tanah tertentu, misalnya tanah yang sangat masam, dibutuhkan pupuk atau perlakuan khusus. Namun kondisi media pada penelitian ini seperti kondisi yang umum ditemukan sehingga pupuk majemuk seperti POC Super V3 Hartani, Hyponex dan AB mix dapat memenuhi kebutuhan unsur hara untuk pertumbuhan dan produksi tanaman dan tidak ada perbedaan antar merek/jenis pupuk. Hal ini berarti ketiga jenis pupuk itu dapat digunakan baik pada sistem tanam biasa (menggunakan media tanah) maupun pada sistem hidroponik. Meskipun dari segi hasil tidak berbeda, namun dalam pemilihan jenis pupuk ini perlu dipertimbangkan beberapa hal lain seperti harga, ketersediaan di lapangan, kemudahan pengaplikasian dan sebagainya.

\section{KESIMPULAN DAN SARAN}

\section{Kesimpulan}

1. Sistem tanam konvensional memberikan pertumbuhan dan produksi tanaman padi yang lebih tinggi daripada sistem hidroponik. Namun demikian, sistem hidroponik dapat memberikan hasil yang cukup layak untuk dikembangkan.

2. Diameter pot mempengaruhi jumlah malai yang dihasilkan tanaman padi. Diameter $40 \mathrm{~cm}$ lebih menghasilkan malai yang lebih banyak daripada pot berdiameter $30 \mathrm{~cm}$.

3. Pupuk Super V3 Hartani, Hyponex dan $\mathrm{AB}$ mix tidak memberikan pengaruh berbeda terhadap pertumbuhan dan produksi tanaman padi, baik pada sistem konvensional maupun pada sistem hidroponik.

4. Tidak ada interaksi antara sistem tanam, diameter pot dan jenis pupuk dalam memperngaruhi pertumbuhan dan produksi tanaman padi.

\section{Saran}

Hasil penelitian menunjukkan bahwa sistem hidroponik padi dapat menghasilkan malai, meskipun hasilnya rendah. Untuk itu diperlukan penelitian lebih lanjut mengenai frekuensi dan dosis pupuk yang optimal, sistem hidroponik yang digunakan dan sistem pengairannya agar dapat memberikan hasil yang lebih tinggi.

\section{DAFTAR PUSTAKA}

Badan Litbang Pertanian, 2012. Teknologi Budidaya Tanaman Sayuran Secara Vertikultur. http://www.litbang.deptan.go.id/ber 
ita/one/918/. Diakses pada tanggal 12 April 2012.

Badan Litbang Pertanian, 2013. Peluang Agribisnis Arang Sekam. [http;//www.pustakalitbang.deptan/ go.id/publikasi/wr254033.pdf].

Diakses pada tanggal 12 Agustus 2013.

Balai Besar Penelitian Tanaman Padi, 2009. Pedoman Umum Peningkatan Produksi Padi Melalui Pelaksanaan IP Padi 400. Balitpa, Sukamandi.

Badan Pengendali Bimas, 1994. Tanaman padi sawah irigasi. Badan Penelitian dan Pengembangan Pertanian, BPTP Sulawesi Selatan.

Direktorat Pengelolaan Lahan, 2009. Pedoman Teknis Pengembangan System Of Rice Intensification (SRI) T.A. 2009. Direktorat Jenderal Pengelolaan Lahan dan Air, Departemen Pertanian, Jakarta.

Hadisuwito, S. 2012. Membuat Pupuk Organik Cair. Agromedia Pustaka, Jakarta.

Kusuma, R., Sari, Y.P., dan Maryadi, Y., 2010. Pengaruh Pupuk Hyponex, Vitabloom dan Gandasil D Terhadap Pertumbuhan Tanaman Tomat (Lycopersicum esculentum Mill.) Varietas Mutiara dengan Teknik Hidroponik Irigasi Tetes.

Lingga, P. dan Marsono. 2004. Petunjuk Penggunaan Pupuk. Penebar Swadaya, Jakarta.

Purwasasmita, M. dan A. Sutaryat. 2012. Padi SRI Organik Indonesia. Penebar Swadaya, Jakarta.
Pusat Penyuluhan Pertanian, 2011. Budidaya Padi. Badan Penyuluhan dan Pengembangan SDM Pertanian bekerjasama dengan Badan Penelitian dan Pengembangan Pertanian, Jakarta.

Rukmana, 2004. Budidaya delapan tanaman pangan unggul. Kanisius, Yogyakarta.

Raihan, S. dan Hairunsyah, 2009. Pemupukan tanaman di lahan kering. Pusat Penelitian dan Pengembangan Tanaman Pangan. Badan Penelitian dan Pengembangan Pertanian, Jakarta.

Salisbury, F.B., dan C.W. Ross. 1992. Fisiologi Tumbuhan, Jilid 2. Lukman D.R., Sumaryono, penerjemah. ITB, Bandung. Terjemahan dari Plant Physiology.

Sarief, E.S. 1983. Kesuburan dan Pemupukan Tanah Pertanian. Pustaka Buana, Bandung.

Setyaningrum, H.D. dan C. Saparinto. 2011. Panen Sayur Secara Rutin di Lahan Sempit. Penebar Swadaya, Jakarta.

Soemartono, 1994. 1994. Usaha tani terpadu. Agromedia Pustaka, Jakarta.

Soenarja dan A.S. Widada, 1994. Bertanam padi sawah. Widjaya, Jakarta.

Suiatna, R.U. 2010. Bertani Padi Organik Pola Tanam SRI. Pustaka Sarul Ilmi, Bandung.

Suprihatno, B., dkk. 2009. Deskripsi Verietas Padi. Balai Besar Penelitian Tanaman Padi, Badan 
Penelitian dan Pengembangan

Pertanian, Departemen Pertanian,

Sukamandi.

Sutanto, R. 2002. Penerapan Pertanian

Organik. Kanisius, Yogyakarta.

Vergara, B.S. 1990. Budidaya Padi Sawah.

Proyek Prasarana Fisik Bappenas, Jakarta.

Yandianto, W. 2003. Bercocok tanam padi.

M2S, Bandung.

* Dosen Program Studi Agribisnis FST UIN Syarif Hidayatullah Jakarta 